\title{
Investigation of the Knowledge Management Process of Schools in Turkey
}

\author{
Cevat Celep and Tuğba Konaklı \\ Faculty of Education, Kocaeli University, Turkey \\ \{celep, tdegirmenci\}akocaeli.edu.tr
}

\begin{abstract}
The aim of this study was to identify the opinions of administrators and teachers about the knowledge management process in primary, secondary and high schools. The population of the study was teachers who work in primary, secondary and high schools in Kocaeli, Izmit. The sample of the study was 270 teachers that were randomly selected. The Knowledge Management Process in Schools Scale that was developed by the researcher was used to collect data. The reliability rate of the scale is 0.96 Cronbach Alpha. The Knowledge Management Process in Schools Scale's Descriptive Factor Analysis results revealed that the scale was comprised of six factors. These factors were: obtaining knowledge; using knowledge; learning knowledge; sharing knowledge; evaluating knowledge; and administrative support. The results of the study revealed that administrative support played an important role in the knowledge management process, and the participants' opinions varied according to their years in service, age and gender.
\end{abstract}

Keywords: Information management process, school, teacher.

\section{Introduction}

Rapid economic, cultural, social and technologic changes in the world mandate modifications in educational systems in many countries. The information age compels development and change in every organization including educational organizations and we have observed educational reforms in Asian-Pacific countries as well as in other parts of the world [1,2]. Also, on an international level, effective school movements and school-based administrative movement reforms have taken place [3, 4].

In a new social and economic organizational period where changes and developments with continuous learning and information acquisition seem inevitable, the structures of school and learning environments change as well [5]. Schools as educational institutions should be multifunctional places where knowledge is produced, used and developed, and should be open to development. They should provide an environment that provides security to humans and team work. They should be open to the public for 24 hours and should satisfy new knowledge needs of the society [6].

Knowledge management is an organizational process where organizational goals are realized with the contributions of people's efficiencies, experiences and thoughts [7]. In other words, it is the determination and use of the shared knowledge that is 
developed by the organization's own experiences and skills [8]. The schools that utilize knowledge management enlarge their capacities to reach results they aim for and adopt a new style with enthusiasm by knowing how to learn together [9].

Teachers, who are the most important components of the educational organization, have their values, beliefs and assumptions about both teaching and school education and the teaching profession prior to starting teaching. In their daily school experiences, they acquire new knowledge, experience and work practices, and new thinking methods about their schools. They acquire experiences and new knowledge and skills when they interact with other people both inside and outside the school [10].

Today, if schools, which are the source of knowledge, adopt knowledge management, they can realize major functions such as directing development and change. Education is an industry of people, and schools are organizations that depend on knowledge. Motivated by these facts, knowledge management is defined as an organization's power of creating values from abstract and real values [11]. The teachers' professional knowledge is the school's most important value that is abstract but at the same time real. Management of teachers' professional knowledge in the field of education is the subject of knowledge management [12]. In the study conducted by Celep and Değirmenci [13] teachers stated that school administrators (managers) in schools in Turkey usually supported knowledge sharing and new knowledge production but they were not in touch with out-of-school resources. In this context, the realization of knowledge management practices in educational organizations and the addressing of problems about the current situation would require further attention. Motivated from this gap in the literature, this study aims to identify the opinions of teachers who are working in primary, secondary and high schools in the city of Kocaeli in the county of Izmit about the knowledge management process in schools. The main question of the study was: "What are the opinions of teachers in primary, secondary and high schools about the knowledge management process in schools?"

The following sub-questions were examined to answer the main question:

1. Is there any significant difference in the opinions of the teachers about the knowledge management process according to their gender?

2. Is there any significant difference about the opinions of the teachers about the knowledge management process according to their age?

3. Is there any significant difference about the opinions of the teachers about the knowledge management process according to their years in service?

\section{Methodology}

\subsection{Research Design and Data Collection}

The research model used in this study was a survey. The Knowledge Management Process in Schools Scale was used to identify the level of perceptions of the teachers about knowledge management in schools. 
The population of the study was teachers who were working in primary, secondary and high schools in Kocaeli, Izmit. The sample of the study was 270 teachers that were randomly selected from 5 primary and 2 secondary schools in Kocaeli.

The data collection tools were developed and based on expert opinions cited in the previous literature by the researchers. The questionnaire included questions about knowledge management in the schools in which the teachers were working. A pool of questions about knowledge management was compiled with the help of previous literature. In the third part of the survey participants were asked 4 questions about the knowledge management process, rating their answers from 1 to 5: "In your opinion, what is the degree of openness of the teachers in your school about renewing themselves professionally?"; "In your opinion, what is the degree of openness of the teachers in your school about being criticised professionally?"; "In your opinion, what is the level of using traditional solution methods when the teachers in your school encounter a problem?"; and "How open are you to share your professional knowledge about teaching with your colleagues?"

\subsection{Developing the Scale}

In developing the scale, the researchers reviewed the previous literature and compiled a pool of questions of 65 items. Likert-type scales were used to measure the teachers' opinions about the knowledge management process. In the scale, 1 referred to 'absolutely disagree', 2 to 'disagree', 3 to 'no opinion', 4 to 'agree', and 5 to 'absolutely agree'. The Kaiser-Meyer-Olkin (KMO) Sample Proficiency Test and the Barlet Global Test were used to test the suitability of the data's factor analyses with the Knowledge Management in Schools Teacher Scale. The KMO value was over 0.60 and the Barlett test showed a 0.05 significance value. Both of these results demonstrated that the data set was suitable for factor analyses $(\mathrm{KMO}=0.911, \chi 2$ Barlett test $=$ 12364.652, $\mathrm{p}=0.000$ ). When 65 items of the scale were analysed according to the factor analyses, 25 of them were removed from the scale either because they carried high load values in more than one factor or their factor load value was lower than 0.30 . The remaining 40 items showed self-values higher than 1 . These were grouped into 6 factors.

The factor loads of the different categories were as follows: obtaining knowledge was between 0.811 and 0.514 ; using knowledge was between 0.768 and 0.516 ; learning knowledge was between 0.761 and 0.525 ; evaluating knowledge was between 0.810 and 0.416 ; and administrative support was between 0.732 and 0.496 . The total variance of the six factors was $63.9 \%$ and the reliability value of the Knowledge Management Process in Schools Scale was $\propto=0.96$.

The arithmetic mean, standard deviation, variance and reliability values of the Knowledge Management Process in Schools Scale are provided in Table 1. When we analyze Table 1, we can see that the dimension with the highest mean is administrative support and the dimension with the lowest mean is evaluating knowledge. 
Table 1. Arithmetic Mean, Standard Deviation, Variance and Reliability Values of the Knowledge Management Process in Schools Scale

\begin{tabular}{|c|c|c|c|c|c|}
\hline Dimensions & Item Numbers & $X$ & sd & Variance & $\begin{array}{l}\text { Reliability } \\
\text { Value }\end{array}$ \\
\hline $\begin{array}{l}\text { Administrative } \\
\text { Support }\end{array}$ & $15,16,13,17,14,28$ & 3.98 & .760 & 5.12 & .89 \\
\hline $\begin{array}{l}\text { Obtaining } \\
\text { Knowledge }\end{array}$ & $21,19,20,22,18$ & 3.77 & .804 & 4.33 & .92 \\
\hline $\begin{array}{l}\text { Using } \\
\text { Knowledge }\end{array}$ & $65,63,62,64,61,58,57$ & 3.75 & .779 & 3.46 & .85 \\
\hline $\begin{array}{l}\text { Sharing } \\
\text { Knowledge }\end{array}$ & $4,5,1,3,10,7,6,2$ & 3.69 & .818 & 40.61 & .90 \\
\hline $\begin{array}{l}\text { Learning } \\
\text { Knowledge }\end{array}$ & $44,43,41,42,36,45,38,9$ & 3.52 & .827 & 7.06 & .90 \\
\hline $\begin{array}{l}\text { Evaluating } \\
\text { Knowledge }\end{array}$ & $25,31,23,24,29$ & 3.33 & .899 & 3.26 & .82 \\
\hline
\end{tabular}

These facts would indicate that the teachers have more positive opinions about administrative support in the knowledge management process and there are some problems about the evaluation of knowledge.

\section{$3 \quad$ Findings}

Some $89 \%$ of the participants in the study stated that they had an email address, $12 \%$ owned a website, $85 \%$ stated that their schools had a website and only $23 \%$ of the participants stated that they read professional magazines, journals or books regularly.

To the question "In your opinion, what is the degree of openness of the teachers in your school about renewing themselves professionally?" the participants on average stated that the level of openness was $\bar{X}=3.25,1$ being not open and 5 being very open. This finding would indicate that the teachers felt that their colleagues were quite open to renew themselves professionally. However, their answer to the question "In your opinion, what is the degree of openness of the teachers in your school about being criticised professionally?" provided a lower average of $\bar{X}=2.85$. Moreover, the average to the question "In your opinion, what is the level of using traditional solution methods when the teachers in your school encounter a problem?" was $\bar{X}=3.20$, and the question "How open are you to share your professional knowledge about teaching with your colleagues?" yielded an even higher average score of $\bar{X}=4.04$. As a result, one can infer that the teachers in this study were open to share knowledge with their colleagues and were inclined to develop themselves professionally; however, they were still using traditional methods to solve their problems and they did not read professional magazines, journals and books regularly. 
When the opinions of the teachers about the knowledge management process was examined, the items "Our principal would finish work that he started" $(\bar{X}=4.21)$, "Our principal would keep his promise" $(\bar{X}=4.17)$, "Our principal has the necessary proficiency that his position requires" $(\bar{X}=4.11)$ had the highest averages. These facts would indicate the value of administrative support in the knowledge management process. On the other hand, items such as "Special situations such as tea hours and informal discussion settings to discuss personal and professional problems are created in our school for teachers to share and interact informally" $(\bar{X}=2.94)$ and "Our teachers' success is symbolically rewarded" ( $\bar{X}=2.98)$ had the lowest averages.

A T-test was utilized to evaluate the opinions of teachers about the knowledge management process in schools based on their gender. The results of the analyses are provided in Table 2. According to these analyses, male teachers had higher averages about learning knowledge $(\bar{X}=3.64)$ and evaluating knowledge $(\bar{X}=3.48)$ compared to female teachers, $(\bar{X}=3.38)$ and $(\bar{X}=3.17)$ respectively. Our analyses also revealed that these differences were significant $(\mathrm{t}(270)=-2.640, \mathrm{p}<.05 ; \mathrm{t}(270)=2.922, \mathrm{p}<.05)$.

Table 2. T-test Results about the Knowledge Management Process in Schools based on Gender

\begin{tabular}{llllllll}
\hline Dimensions & Gender & $\mathrm{n}$ & $\bar{X}$ & $\mathrm{sd}$ & $\mathrm{df}$ & $\mathrm{t}$ & $\mathrm{p}$ \\
\hline Obtaining & Female & 135 & 3.73 & .788 & 275 & .729 & .466 \\
Knowledge & Male & 135 & 3.80 & .824 & & & \\
Using & Female & 135 & 3.67 & .796 & 275 & .146 & .145 \\
Knowledge & Male & 142 & 3.81 & .764 & & 0 & \\
Learning & Female & 135 & 3.38 & .836 & 275 & .266 & $.008^{* *}$ \\
Knowledge & Male & 142 & 3.64 & .806 & & 2 & \\
Sharing & Female & 135 & 3.65 & .844 & 275 & .905 & .366 \\
Knowledge & Male & 142 & 3.74 & .791 & & & \\
Evaluating & Female & 135 & 3.17 & .900 & 275 & .291 & $.004 * *$ \\
Knowledge & Male & 142 & 3.48 & .881 & 275 & 6 & \\
Administrative & Female & 135 & 3.94 & .704 & 275 & .928 & .354 \\
Support & Male & 135 & 4.02 & .812 & 275 & & \\
\hline Not $* * p$ & & & & & & & \\
\hline
\end{tabular}

Note: $* * \mathrm{p}<.01 ; * \mathrm{p}<.05$.

The results of the questionnaire in terms of the participants' opinions about the knowledge management process based on gender revealed that male teachers had more positive opinions about learning knowledge and evaluating it compared to female teachers.

To compare the participants' opinions about knowledge management process based on the ages of the teachers, an ANOVA test was used. The results of the analysis are given in Table 3.

The results of the analyses revealed that the teachers' opinions about the knowledge management process in schools differed significantly according to their ages $(\mathrm{F}(7-270)=2.462, \mathrm{p}<.05)$. 
Table 3. ANOVA Results about the Knowledge Management Process in Schools based on Age

\begin{tabular}{lllllll}
\hline Dimensions & & $\begin{array}{l}\text { Total } \\
\text { Square }\end{array}$ & df & $\begin{array}{l}\text { Average of } \\
\text { Squares }\end{array}$ & F & p \\
\hline Obtaining & Among Groups & 6.704 & 4 & 1.676 & 2.65 & .034 \\
Knowledge & Within Groups & 171.24 & 271 & .632 & 2 & $*$ \\
& Total & 177.95 & 275 & & & \\
Using Knowledge & Among Groups & 3.265 & 4 & .816 & 1.35 & .251 \\
& Within Groups & 163.72 & 271 & .604 & 1 & \\
Learning & Total & 166,99 & 275 & & & \\
Knowledge & Among Groups & .398 & 4 & .099 & .143 & .966 \\
& Within Groups & 187.35 & 270 & .694 & & \\
Sharing & Total & 187.75 & 274 & & & \\
Knowledge & Among Groups & 3.471 & 4 & .868 & 1.30 & .270 \\
& Within Groups & 180.60 & 271 & .666 & 2 & \\
Evaluating & Total & 184.07 & 275 & & & \\
Knowledge & Among Groups & 1.367 & 4 & .342 & .419 & .795 \\
& Within Groups & 222.12 & 272 & .817 & & \\
Administrative & Total & 223.49 & 276 & & & \\
Support & Among Groups & 2.564 & 4 & .641 & 1.11 & .352 \\
& & & & & 1 & \\
& Within Groups & 155.76 & 270 & .577 & & \\
\hline
\end{tabular}

Note: $* * \mathrm{p}<.01 ; * \mathrm{p}<.05$

To determine the source of the difference, a Tukey test was administered. The results of the Tukey test are given in Table 4.

Table 4. Tukey Test Results about the Knowledge Management Process in Schools based on Age

\begin{tabular}{llllll}
\hline Dimensions & (I) Age & (J) Age & (I-J) Mean Difference & Sh & $\mathrm{p}$ \\
\hline Obtaining & $20-30$ & $31-40$ & -.02602 & .11333 & .999 \\
Knowledge & & $41-50$ & .17083 & .14447 & .761 \\
& & $51-60$ & -.10476 & .19441 & .983 \\
& & 61 and older & 1.60000 & .56891 & $.042^{*}$ \\
& \multirow{2}{*}{$31-40$} & $20-30$ & .02602 & .11333 & .999 \\
& & $41-50$ & .19685 & .13529 & .593 \\
& & $51-60$ & -.07875 & .18769 & .993 \\
& & 61 and older & 1.62602 & .56665 & $.036^{*}$ \\
\hline
\end{tabular}

Note: $* * \mathrm{p}<.01 ; * \mathrm{p}<.05$

To compare the participants' opinions about the knowledge management process based on years in the service, an ANOVA analysis was used. The results of the analysis are given in Table 5. 
Table 5. ANOVA Results about the Knowledge Management Process in Schools based on Years in Service

\begin{tabular}{lllllll}
\hline Dimensions & & $\begin{array}{l}\text { Total } \\
\text { Squares }\end{array}$ & df & $\begin{array}{l}\text { Average } \\
\text { of } \\
\text { Squares }\end{array}$ & & \\
& & & & p & \\
\hline Obtaining & Among Groups & 2.188 & 7 & .438 & .672 & .645 \\
Knowledge & Within Groups & 175.762 & 270 & .651 & & \\
& Total & 177.950 & 277 & & & \\
Using & Among Groups & 2.903 & 7 & .581 & .955 & .446 \\
Knowledge & Within Groups & 164.090 & 270 & .608 & & \\
& Total & 166.992 & 277 & & & \\
Learning & Among Groups & .513 & 7 & .103 & .147 & .981 \\
Knowledge & Within Groups & 187.242 & 270 & .696 & & \\
& Total & 187.754 & 277 & & & \\
Sharing & Among Groups & 3.922 & 7 & .784 & 1.176 & .321 \\
Knowledge & Within Groups & 180.149 & 270 & .667 & & \\
& Total & 184.071 & 277 & & & \\
Evaluating & Among Groups & 6.490 & 7 & 1.298 & 1.621 & .155 \\
Knowledge & Within Groups & 217.002 & 270 & .801 & & \\
& Total & 223.492 & 277 & & & \\
Administrative & Among Groups & 6.930 & 7 & 1.386 & & \\
Support & Within Groups & 151.401 & 270 & .563 & 2.462 & $.033^{*}$ \\
\hline & Total & 158.331 & 77 & & & \\
\hline
\end{tabular}

Note: ${ }^{* *} \mathrm{p}<.01 ; * \mathrm{p}<.05$.

Based on the results of the analyses, there was a significant difference concerning administrative support in the knowledge management process $(\mathrm{F}(7-270)=2.462$, $\mathrm{p}<.05)$. However, there was no significant difference about obtaining knowledge $(\mathrm{F}(7-270)=.672, \mathrm{p}>.05)$; using knowledge $(\mathrm{F}(7-270)=.955, \mathrm{p}>.05)$; learning knowledge $(\mathrm{F}(7-270)=.147, \mathrm{p}<.05)$; sharing knowledge $(\mathrm{F}(7-270)=1.176, \mathrm{p}>.05)$; or evaluating knowledge $(\mathrm{F}(7-270)=1.621, \mathrm{p}>.05)$ compared to administrative support.

To determine the source of the difference about teachers' opinions about the knowledge management process based on years of service, a Tukey test was administered. The results of the Tukey test are given in Table 6 .

Based on the Tukey test results, the teachers with 26 or more years in service had more positive opinions about the knowledge management process compared to teachers with years in service between 21 and 26. This would show that teachers with 26 or more years in service are more inclined to support, and had higher trust in terms of principals' actions and thoughts. Based on Celep and Değirmenci's (2005) study, teachers between the ages of 41 and 50 had more trust about the knowledge management process compared to others. In this context, one can argue that age and years in service would have some effect on the knowledge management process. 
Table 6. Tukey Test Results about the Knowledge Management Process in Schools based on Years in Service

\begin{tabular}{llllll}
\hline Dimensions & (I) Age & (J) Age & $\begin{array}{l}\text { (I-J) Mean } \\
\text { Difference }\end{array}$ & Sh & P \\
\hline Administrative & & 1-5 years & .28054 & .20709 & .754 \\
Support & & 6-10 years & .19712 & .20937 & .935 \\
& \multirow{2}{*}{ 26 and more } & $11-15$ years & .53725 & .20906 & .108 \\
& & $16-20$ years & .49530 & .23094 & .268 \\
& & 21-25 years & 1.24306 & .54213 & $.046^{*}$ \\
\hline
\end{tabular}

Note: ${ }^{* *} \mathrm{p}<.01 ; * \mathrm{p}<.05$

\section{$4 \quad$ Results and Discussion}

Knowledge management is a relatively young but increasingly popular field of organisational study [14]. A pertinent definition is: "the process of identifying, capturing, organizing and disseminating the intellectual assets that are critical to the organisation's long-term performance" [15]. Sallis and Jones [14] claim that many corporate institutions do not have a specific strategy for knowledge management, and "of the few that do have such a strategy, almost none are in the education sector" (p. 63). While the concept of knowledge management has been examined extensively within the business context, very little is known about how the knowledge management process may benefit educational institutions [16].

School knowledge management is involved in the process of knowledge acquisition, accumulation, sharing, transformation, application, innovation, integration and diffusion, which is impacted by school leadership, organizational culture, information technologies, performance management, and other enablers [17]. The results of this study revealed that even though the teachers were open to renew themselves professionally through a knowledge management process, they are still using traditional methods to solve their problems. Moreover, administrative support plays a facilitative role in the knowledge management process, but the reward system is not satisfactory. The opinions of the teachers about the knowledge management process was analyzed on their gender and it was found that the male teachers had more positive opinions about the knowledge management process compared to female teachers. Another point of interest from this study was the years in service for the teachers, and the findings that teachers between the age groups of 20 to 30 and 31 to 40 had more positive opinions about obtaining knowledge compared teachers who were 61 or over at the time of the study. When years in service was examined, the findings revealed that teachers with 26 years or more in service had more positive opinions about administrative support compared to their colleagues with different years in service. This would imply a greater trust from more experienced teachers towards the administration.

When the opinions of the teachers are interpreted about the knowledge management process as a whole, the teachers highlighted the importance of administrative support. Male teachers and teachers under the age of 40 had positive opinions about 
the knowledge management process particularly. To address problems that the study revealed, one can support teachers who are older than their colleagues about obtaining knowledge and increase activities that might help female teachers join the knowledge management process. Moreover, to have a more effective knowledge management process, some informal meetings could be organized and teachers taking part in these meetings could be rewarded to change their opinions to make them more positive.

\section{References}

1. Cheng, Y.C., Townsend, T.: Educational Change and Development in the Asia-Pacific Region, Challenges for the Future. Swets \& Zeitlinger, The Netherlands (1999)

2. Cheng, Y.C.: Recent education developments in South East Asia: An introduction. School Effectiveness and School Improvement. An International Journal of Research, Policy and Practice 10(1), 3-9 (1999)

3. Banathy, S.H., Jenks, C.L.: The transformation of education: by design. International Journal of Educational Research 19(2), 105-145 (1993)

4. Sheeran, T.J., Sheeran, M.F.: Schools, Schooling and Teachers: A Curriculum for the Future. NASSP Bulletin (1996)

5. Öğüt, A.: Bilgi Çağında Yönetim (2. Baskı). Nobel Yayıncılık, Ankara, Turkey (2003)

6. Balay, R.: Küreselleşme, Bilgi Toplumu ve Eğitim. Ankara Üniversitesi Eğitim Bilimleri Fakültesi Dergisi 37(2), 61-82 (2004)

7. Todd, R.: Reading the future: Knowledge Management 1: background and key concepts. Scan 18, 42-46 (1999)

8. Celep, C., Çetin, B.: Bilgi Yönetimi: Örgütlerde Bilgi Paylaşım Kültürü Yaratma. Anı Yayıncılık, Ankara, Turkey (2003)

9. Güçlü, N., Otirofski, K.: Bilgi Yönetimi. Türk Eğitim Bilimleri Dergisi 4(4), 351-371 (2006)

10. Yuen, P.Y., Cheng, Y.C.: Leadership for Teachers Action. The International Journal of Educational Management 14(5), 198-209 (2000)

11. Sveiby, K.E.: Manager in creative environments. Svenska Dagbladet, Stockholm, Sweden (1992)

12. Celep, C., Çetin, B.: Teachers' perception about the behaviours of school leaders with regard to knowledge management. International Journal of Educational Management 19(2), 102-117 (2005)

13. Celep, C., Değirmenci T.: Eğitim Örgütlerinde Bilgi Yönetimi. XIV. Ulusal Eğitim Bilimleri Kongresi Pamukkale Üniversitesi Eğitim Fakültesinde sunulmuş bildiri, Denizli, Turkey (September 28-30, 2005)

14. Sallis, E., Jones, G.: Knowledge management in education. Kogan Page, London (2002)

15. Debowski, S.: Knowledge management. John Wiley \& Sons, Milton (2006)

16. Tippins, M.: Implementing knowledge management in academia: Teaching the teachers. The International Journal of Educational Management 17(6/7), 339-346 (2003)

17. Zhao, J.: School knowledge management framework and strategies: The new perspective on teacher professional development. Computers in Human Behavior 26, 168-175 (2010) 